\title{
University as a platform: an evolutionary process towards an open educational ecosystem in Europe
}

\author{
Gonzalo León, Alberto Tejero, Natalia Dévora and Iván Pau \\ Universidad Politécnica de Madrid ${ }^{1}$
}

\begin{abstract}
Universities are very stable institutions where their basic role in society is still alive after centuries; nevertheless, the way to provide it has deeply changed due to the generation of knowledge, evolution of technology, and evolution in internal and external governance and funding schemes. Even if those changes were successfully surfed and universities are still recognised in society as key actors for education and knowledge generation, new challenges are on the way and the smooth adaptation approach used in the past could be not valid anymore in front of disruptive societal changes. In fact, traditional higher-education value-chain is being challenged with the introduction of new actors in the higher education process and the emergence of IT-based disruptive learning models, which impact on university performance and governance. The main goal of this paper is to analyse how public universities' structures should efficiently evolve in that context while preserving their role in society. We are aware that many of the findings could be also applied to private universities although regulatory contexts are different.
\end{abstract}

The article offers a global view on public university governance challenges motivated by the digitisation of society and how Western universities should address them in order to keep a prominent role in the future knowledge society, where more complex educational ecosystems will be in place. The objective is to analyse the relative importance and interaction of a set of drivers for transforming universities' structures in the context of a digital economy and how the (fragmented) answers provided today by universities over the world should evolve in the future towards a consistent policy and organisational mix by using concepts borrowed from digital platforms and collaborative economy. The article is mainly focused on the situation in the European Union (EU) linked to policy actions launched by the European Commission and EU Member States, although some action lines could be shared in broader geographical contexts.

The analysis presented in the paper is focused on the applicability of the concept of (digital) higher educational platforms and how they can modify the provision of higher education services within an open education ecosystem in close cooperation with other actors. The impact in the higher-education value chain implies that several public and private actors will occupy positions formerly exclusively linked to universities; this evolution and their consequence are presented in the article through a number of potential trajectories. Finally, the article discusses a much more disruptive perspective by considering the future role of universities as "specialised learning platforms" for providing higher educational services over the world with weaker links to territory, and its derived consequences for new or pre-existent universities.

\section{Keywords}

Universities; knowledge triangle; educational models; blended learning; governance; digital platforms; platform-based higher educational services; knowledge ecosystems.

\footnotetext{
${ }^{1}$ The opinions contained in this article do not represent any formal position of the Universidad Politécnica de Madrid and they exclusively correspond to the authors.
} 


\section{Introduction}

At the end of the last century up to 85 institutions surviving since 1520 in Western countries were identified (Kerr, 1987). Catholic Church, obviously, was in the list with the Parliaments of Isle of Man, Iceland and of Great Britain some Swiss cantons and others, but many European universities, 70, were in the list too. Even if the concept of "university" has evolved and enriched over time, universities were able to survive for centuries until our days and they represent an extraordinary case of institutional resilience over five hundred years.

From our point of view, this fact came from the recognition that the core "university mission" is deeply anchored in mankind evolution: to facilitate the transmission of consolidated knowledge to younger generations and to generate new knowledge to pass the baton of progress towards future generations. This historical university resilience is also rooted in a governance model where respect to traditions, hierarchy, and academic freedom are subtly merged and balanced.

Even if Western universities were able to reinvent themselves a number of times in history by deeply adapting their curricula, by opening their doors to move from elite to mass education, by modifying their internal structure and governance, and by widening their funding sources, they still perform their core missions as they were conceived in the past; even if the performance of some learning processes had improved due to the intensive use of new technologies (mainly ICT-based tools) and academic contents' subjects suffered dramatic changes to accommodate science and technology development.

Universities are not isolated entities immune to society changes; they also suffer the consequences of other deep changes in society and they will share with other institutions the fate of society evolution (Etzkowitz et al., 2000; Marshall, 2018). During this decade, the fast evolution towards the so-called "digital economy" and the exponential growth and availability of innovative solutions based on "digital platforms" embedded in the so-called collaborative economy are affecting all public and private entities by disrupting the value-chains of all economic sectors.

The higher education sector is not immune to it. Then, the key question at this stage is to assess at what extent universities will continue playing their main role in society as the main focus for generating and transmitting knowledge to future generations or it should be a responsibility increasingly shared with other actors (Aronowitz, 2000; Verger et al., 2016; Menezes and Pinto, 2016), even when its core values were still preserved. Today, deep changes can find Western universities weakened after years of deep economic crisis, without university degrees as a guarantee to get a job, and with inadequate internal governance mechanisms to react on time in front of deep contextual changes.

The objective of the paper is to serve for an internal debate on the university policies and strategies towards the future. This article explores how the deployment of digital platform business models could affect public universities' roles in the future, and how this time something more essential than the slight reaction to changes occurred in the past is needed to cope with. The disruption of the whole education value-chain deserves attention to assess the role played by public universities in society and it deserves deep structural changes.

First, the article will analyse and clarify the key factors of the present higher education valuechain related to universities; then, disruptive changes affecting universities and their impact on the value-chain are presented as challenges to be addressed and opportunities to improve the university footprint in society; based on that, some "answers" to those challenges in the structure and governance of universities are presented and evaluated. Finally, a roadmap to the 
near future of European universities is discussed to extract from it some policy guidelines for their strategic institutional re-positioning.

\section{Today's university-based value-chain}

\subsection{Modernisation process of European public universities}

At the end of the last century the European Union (EU) was well-aware of the urgent need to reinforce the role of European universities in the construction process of the so-called "European knowledge society" where not only knowledge generation and wide absorption was essential but also its application and use would demand highly skilled citizens and professionals. This is the basis of the well-known concept of "knowledge triangle" (Maassen and Stensaker, 2011) where universities meet together with other entities like enterprises and public research centres. Conceptually, the so-called "knowledge policies" ranging from education, research and innovation policies should be jointly designed and implemented by governments and institutions to be successful in an integrated way.

Figure 1 depicts a global view of the effort made by the EU where the European Higher Education Area (EHEA, 1999), the European Research Area (ERA) (COM, 2010), and a broad range of innovation activities firmly tied to regional policies and (since 2014) deeply embedded in the framework programme (H2020) (EU, 2013) coexist together. To realize that political ambition, the European Union is pushing since 2010 a long-term process of structural reform of European universities $^{2}$ to improving their global competitiveness (HLG, 2013), (Eurydice, 2017), (SWD, 2017).

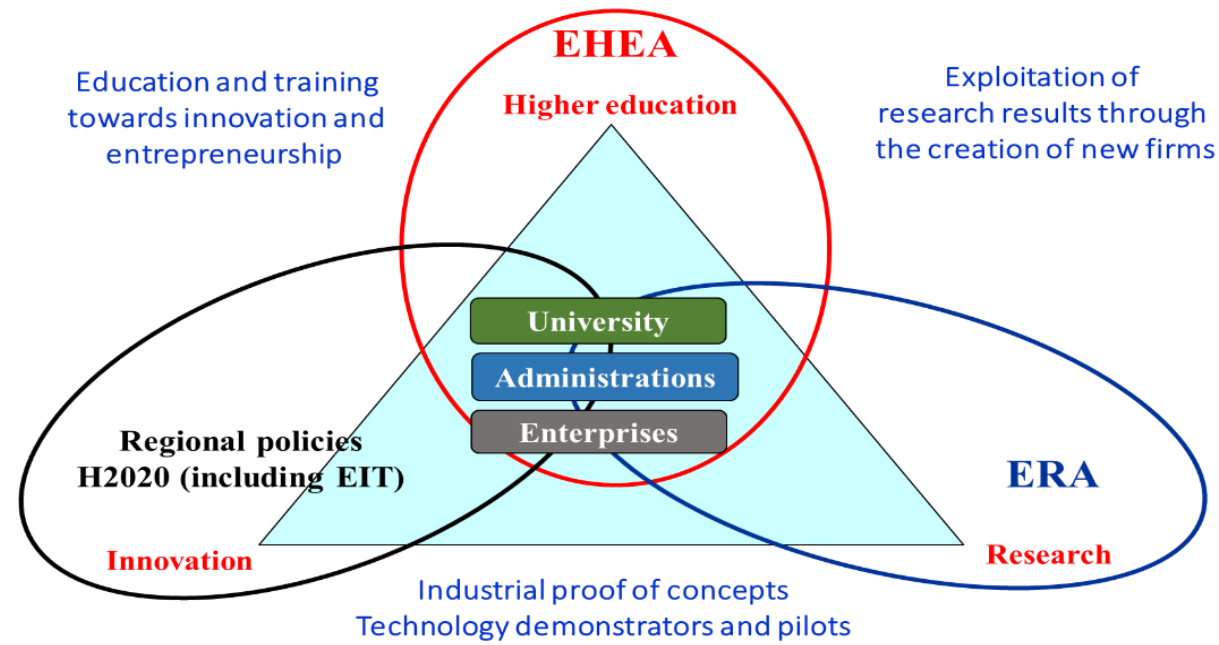

Figure 1. The EU in the knowledge triangle (source: own elaboration)

Main action lines behind the "modernisation process of European universities" are as follows:

- Strengthening of the "excellence on diversity" principle to permit each university to define its own objectives and thematic priorities in teaching, research and innovation according to context and capabilities.

- Creating of "stable partnerships" between universities and external public and private entities like the productive sector to dynamically reorient their educational offer and research lines in the international context to the required skills.

\footnotetext{
${ }^{2}$ The term also includes in this discussion paper other "high-level" education entities (e.g. engineering schools in some European countries).
} 
- Increasing their "regulatory and financial autonomy" to be able to set-up the maximum independence in the management of their assets and find the appropriate governance and structure.

As a matter of fact, the evolution of public universities in the EU has been dissimilar since 2000 and a number of diverse models and situations can be found in the EU Member States; a sense of "policy experimentation" is still on the table because common consensus was not still got. This fact is also supported by the implementation of the university autonomy principle linked to the "excellence on diversity" goal, which is reflected in national and regional legislation and derived university by-laws. This diversity could be even wider in those European countries where regional power is stronger and public universities depend on regional governments; each regional government can also dictate specific priorities to universities linked to territory as a basis for funding (i.e. funding mechanisms based on performance and alignment to regional strategies).

\subsection{Evolution of the higher education value-chain}

After describing the higher education context in the previous sections, attention should be paid to the way that European public universities could perform better their social mission in the future. For that objective, the equivalent of the "value-chain model" widely used as a useful analysis tool in other economic sectors (Normann and Ramirez, 1993; Gereffi and FernandezStark, 2016), can be also applied to analyse the evolution of the high-level academic sector.

The analysis in this section will be focused on European public universities, although many of the insights could be also applied to private universities, which have inherited similar approaches. In fact, this distinction is blurring, as we will discuss later in this article.

The present public university-based education value-chain model used by European universities can be summarised as follows:

1. The academic offer of European universities is defined by themselves, but within the legal framework set-up by governments, to ensure quality and social/governmental recognition of their graduates. The flexibility degree to define in detail the academic offer depends on national and regional regulations (ranging from national-wide to simple university recognition of their own academic degrees ${ }^{3}$ ), on the internal capacities and adequate market analysis to attract students, and on the academic offer to give students the maximum employability once graduated.

2. Academic degrees are implemented by individual universities, by using their own staff and implemented in their proprietary (non-shared) premises, with facilities for teaching and research obtained from several sources: University premises visibility is a must to attract students. Academic offer jointly designed by two or more universities to receive a single university degree is still an exceptional case in undergraduate courses, although it is becoming more common for master's degrees (León, Leceta and Tejero, 2017).

3. The awareness and marketing of the academic offer to potential targeted students is made by universities themselves to cover the annual offered places. This process has a limited impact on the budget of the public universities due to the low tuition fees imposed by

\footnotetext{
${ }^{3}$ This factor constitutes a key distinction between Anglo-Saxon and continental models of universities. In several European countries, the legislation indicates how to obtain an academic degree confers the graduate "professional rights" delegates to society (many engineering, architecture or medicine degrees provide that). In other cases, there is a clear separation between academic skills and professional rights.
} 
governments and because there was an implicit market segmentation, where the allocation of students to specific universities is based on geographical concepts of proximity.

4. Student's decision is made at the individual level based on his/her own interest to choose one university degree (criteria range from short-term views based on affinity and wishes on specific degrees, and long-term views based on potential employability and professional development related to the chosen degree). The final decision is also modulated by the qualifications obtained by students during high-school studies (or specific entry exams conducted by universities themselves when and where this system applies) and a number of factors like individual students' marks, geographic proximity, tuition fees, reputation of the university or chosen degree (rankings and/or word of mouth), and family pressures or economic constraints.

5. Enrolment in university courses in one university is got after fulfilling academic requirements (i.e. numerus clausus if it were the case, for the selected university degree) and the effective payments of tuition fees. Some control of physical presence of the students is also regulated although national cultural bias allows students' freedom to assist. For master's degrees, much more flexibility is available... and advisable. Furthermore, the possibility to study in two or more universities to receive a single degree has increased in the EU with the expansion of the ERASMUS programme, with benefits beyond academic results. This issue relates to the internationalisation model of the university where students are not only local ones ${ }^{4}$.

6. Education processes are conducted by using a mix of learning methods (e.g. face-to-face lectures, use of technical labs, seminars, project-based learning, groups' assignments, and the follow-up of on-line modules, blogs, etc.) individually applied to the most appropriate thematic subjects. A wise combination of these subjects constitutes the full academic year (with an allocation of 60 ECTS), and some academic years compose the curriculum for university degrees (3-4 years for university degrees and 1-2 years for master degrees depending on national regulations). In all cases, the responsibility of providing the subjects' contents relies on the university.

7. Grading is performed individually by students through a set of evaluation processes which are conducted at individual level (group level evaluation can be also applied as a complementary grading process during the academic year) to assess if the pre-defined set of learning outcomes were well apprehended by enrolled students. Recent emphasis is placed on the application of continuous evaluation systems instead of the more traditional procedure based on written exams (usually concentrated at the end of each academic semester).

Figure 2 depicts the main interactions between the seven main steps of the higher education value-chain.

\footnotetext{
${ }^{4}$ Knight (2015) describes a range of different internationalisation models including the classic model where the university engages internationally in a range of initiatives while remaining anchored in a national context, the satellite model where internationally based facilities extend the reach of the universities' activities into other countries and the co-funded model where multiple partners collaborate in the creation of hybrid universities.
} 


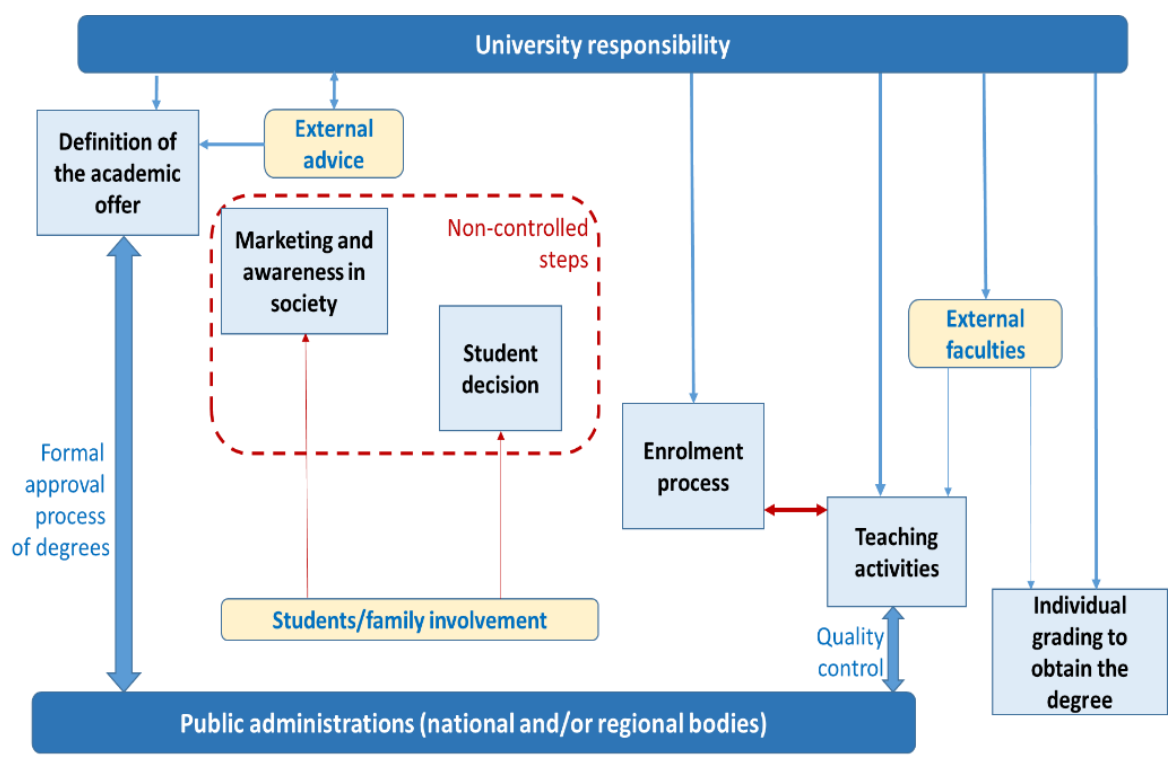

Figure 2. Simplified higher education value-chain (Source: own elaboration)

Two main actors, universities and public administrations, take the lead in the value-chain while other actors play complementary roles. Nowadays; the support for "external advice" offered by industry or other type of entities, or the participation of external experts in regular courses still have marginal weight in public university processes.

\subsection{Mismatch between offer and demand}

From a wider social perspective, discussion is heating in many European countries (or at the common EU level) around the assessment of the value of university graduates generated and the matching with societal needs. As indicated by the European Commission (SWD, 2017), some economic areas in Europe suffer a shortage of skilled professionals. The combination of shortages of STEM professionals, ICT professionals and "teachers" call for action to universities in order to reduce the gap and/or mismatch. Therefore, Universities are increasingly pressed to offer "solutions to the existing gap" by modifying their academic offer and also by working closer to other actors to align curricula and skills to demands.

One of the areas where this mismatch has more relevance refers to the digital skills required to any university student. The European Commission (SWD, 2018) notices how its Communications on education, such as on the "Modernisation of Higher Education" (2011) and "Improving and Modernising Education" (2016), and "A Digital Single Market Strategy for Europe" (2015), highlighted "The New Skills Agenda for Europe (2016) placed the need for digital competence as a priority, and called on Member States to ensure they have comprehensive strategies in place for improving the digital competence of people".

In the same document (COM, 2016a): "Improving the digital capacity of education, training and learning providers by supporting the use of self-assessment tools can help them make best educational use of digital technologies to enhance teaching and learning, but also support the development of digital competence specifically".

Another driver for change was the introduction of "innovation and entrepreneurship" (I\&E) skills in university degrees. These activities were implemented to complement (and not substitute) the usual perspective of focusing on technical issues during the curricula development. The approach termed as " $T$-based" educational model (see figure 3) has been extensively addressed 
by the European Institute of Innovation and Technology (EIT) (EIT, 2008), and specifically for its "knowledge and innovation communities" (KIC).

EIT Digital (EIT Digital, 2017a) has promoted the use of T-based model in its master and doctorate schools where a large group of European universities cooperate in educational processes (León et al., 2017). The implementation of a "T-based education model" at the master level in EIT Digital implies a "major" in one of the eight technical domains approved today (typically with a $75 \%$ of the total allocated effort) and an "innovation and entrepreneurship (I\&E) minor" (typically with a $25 \%$ of the total allocated effort).

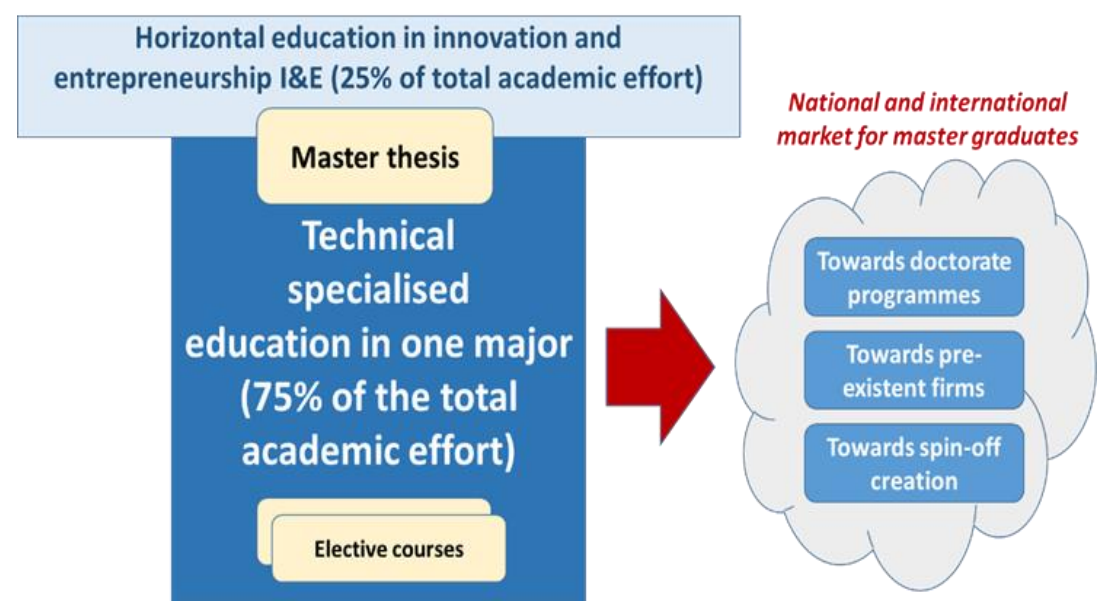

Figure 3. T-based model for master level education in engineering (Source: own elaboration)

This approach intends to generate university graduates (mainly focused on technical and engineering studies) with a "double profile" better adapted to face the challenges of a digitalised society and to boost their future employability in Europe. Some of the education process (both in the I\&E part and in the technical part) could be covered by on-line techniques while others are still addressed by using traditional face-to face models. This is the concept of "blended learning" which is being assumed by EIT Digital as a distinctive feature of the EIT Digital learning model (León and Tejero, 2016; Dion et al., 2018; Pisoni et al., 2018).

This trend is also strengthened with the "unbundling" of university courses into smaller components (so-called modules or "micro-courses") à la MOOCs (Skiba, 2012); it has been presented as a wise approach for facilitating the access to professionals which cannot devote substantial periods of their time in the work place to follow a full academic course as full-time students.

Even when this process fits well for life-long learning goals in firms, it is doubtful to ensure its usefulness as a substitution of traditional academic years for full-time students without a parallel mentoring job. Some recent experiences in EIT Digital with micro-masters indicate a growing interest from firms in testing the usefulness of that approach, but it will be necessary more time to assess its full effectiveness as a learning approach in areas that are evolving very fast.

As a summary, universities (and governments) are still fully convinced in the need of preserving the social value of universities by keeping their most relevant features as they were conceived in Western history for centuries and to ensure that the institutional strategy be independent of small perturbations. The open question is to assess if minor adaptations to the high education value-chain, resulting from the introduction of new information technologies and the 
modification of learning processes based on its deployment and use, will be enough to cope with deeper changes coming from disruptive technologies that are maturing very fast.

\section{Digital disruptions in the higher education value-chain}

\subsection{Digital skill challenges}

The deployment of infrastructure and applications in the ICT domain has deeply transformed all economic sectors over the entire world. Today, the process of "digital transformation" of public (e.g. governmental agencies, hospitals, schools) and private entities (from large corporations to small and medium enterprises) constitutes one of the most important driving forces to ensure its global competitiveness with strong impacts on their internal organisation, employment and quality of life (Matt et al., 2015).

The EU launched a long-term process framed in the development of the so-called "European Digital Agenda" (COM, 2014) by identifying some indicators and setting-up target values for each of them to reach in a given period of time. This process was also replicated at national level placing more emphasis in some specific issues depending on the starting point and priorities of each Member State. One of the key elements to realize the political goals of the European Digital Agenda is to ensure the success in the "digital skills" mismatch challenge as described above.

A good number of studies, reports and statistics demonstrates the current shortage of professionals in Europe with the right set of digital skills to move forward the competitiveness of public and private institutions (OCDE, 2012), (ULAB, 2014), (OECD, 2017). The lack of skilled people is not only restricted to university level and it extends beyond it to cover from end-users (i.e. to ensure digital literacy for average citizens) to other professionals in the workplace.

This situation is more acute in some European countries because the number of STEM ${ }^{5}$ graduates generated by universities is declining. One of the reasons is the common perception among students that future salaries and jobs will not compensate for the required effort to graduate in STEM-related university degrees even when salaries remain higher than graduates in other disciplines (OECD, 2017). Notice that if salaries of professionals in those areas are moving up, public universities will have even more difficulties than they face today to retain talent and young faculties; they will go out to find better and faster professional career prospections.

Besides that, multidisciplinary university degrees to educate students with systemic views capable of integrating several concepts and technologies will be even more necessary than today... and universities are not strategically addressing that challenge yet, due to internal organisational constraints (e.g. department fragmentation and by-laws reaction times) anchored in their own history.

Main challenge is to assess if universities are ready to address the mismatch gap by themselves or, if it will be necessary to complementarily rely on other types of institutions more capable to provide the number of skilled professionals necessary to attend the growing demand.

\subsection{Access to advanced equipment and facilities}

Many European universities are aware of the relevance to access to sophisticated equipment as a key issue to keep their global competitiveness in university degrees related to emerging technologies for STEM degrees. Unfortunately, the economic crisis suffered in the last decade in many European universities and the associated reduction of governmental budgets for higher

\footnotetext{
${ }^{5}$ STEM stands for Science, Technology, Engineering and Mathematics.
} 
education have had a negative impact in the acquisition, upgrade or maintenance of sophisticated equipment for students' labs. The risk of technological obsolescence of educational labs and the difficulties to provide university students with the access and handson experience in the equipment required by industry is a warning signal. Here, a subtle "equipment-divide gap" is emerging.

More efficient approaches are feasible if universities find the way of partnering with other public and private entities in order to purchase and share advanced equipment for educational purposes and to access to sophisticated IT platforms as a market place for accessing equipment or material goods (Bauer, 2014). Today, the signature of specific agreements for sharing educational facilities between universities face big reluctance between managers, even if they were ready to cooperate with other universities in research activities.

Governments are also pressing public universities, which depend on them to reach bilateral or multilateral agreements when they feel the need to optimize the public financial effort. This attitude requires to be carefully balanced within the legally protected "autonomy of universities" and governments prefer to propose it as a "rewarding mechanism" (provision of extra funds) linked to specific projects.

The case of "excellence campus programmes" launched in France, Spain or Germany years ago was an example in this direction even when no continuity was ensured as a consequence of the economic crisis (Delgado and León, 2014; Delgado, 2017). In these cases, additional budgets (not part of the stable block funding) were offered by governments in open calls, if selected universities propose sound institutional strategic plans to share capacities and to create stable partnerships together with other public and private universities. The intention from governmental agencies with these "excellence programmes" was to reward (via extra-funding) those "structural reforms" of universities aiming at competing better at international level by funding specific programmes based on some "merging" actions (i.e. academic degrees, faculties in one area, or even whole universities) in order to get the critical mass to compete better and to ensure long-term sustainability.

\subsection{Towards an open educational ecosystem}

\subsubsection{Drivers for change}

An even more relevant trend concerning universities' evolution is the recognition of the possibility or convenience that their educational services could be provided through long-term partnerships with public and private external entities not necessarily located in the same country. These developments point out towards new "hybrid models" where universities operate their core academic activities in symbiosis with their enabling partners. The rationale behind this evolution is two-fold:

1. To be able to quickly adapt the academic offer to emerging market needs by relying on agreements with external experts and capabilities when internal resources were not enough or when they were not ready. This approach allows universities to find shortcuts to avoid the substantial time required in the public system to convert a new degree in a reality.

Additional human and material resources can be offered by other entities; then, universities do not need to base their offer of academic degrees only on internal capabilities. One of the easiest well-known approaches for that is the provision of "on-line" degrees by using advanced tools (e.g. to develop or acquire software platforms, pre-designed educational contents or even access to remote labs!) and through the participation of external experts individually identified or through the signature of agreements with service providers. 
The need to accelerate innovative academic offer where administrative conditions delay purchase and hiring processes of faculties are overregulated is forcing more active universities to combine the provision of educational services with selected partners and to distribute potential benefits among all participants. This trend is being progressively adopted in case of post-graduate studies oriented to specialised professionals.

2. To increase the efficiency and performance of the education process by focusing public universities in those areas where they can offer a substantial added-value (e.g. knowledge certification, grading, postgraduate courses with advanced equipment to bridge them with research, etc.) and not in other areas where private entities could perform better.

One case where this approach applies is the provision of technical platforms for students to access to media contents, interact with peers through specialised social networks, schedule virtual tuition, etc. As any other entity, universities can implement these services but usually they have not internally the right profile neither the experience for that. Why not to rely on external partners?

Figure 4 offers a high-level view of the main drivers for change which condition decision-making by universities. Some drivers are internal to the university in order to improve their positioning (e.g. in international rankings and with their partners) and efficiency (e.g. best use of human and material resources); others are external drivers motivated by shifts in interest or priorities of stakeholders (e.g. the creation of a new faculty).

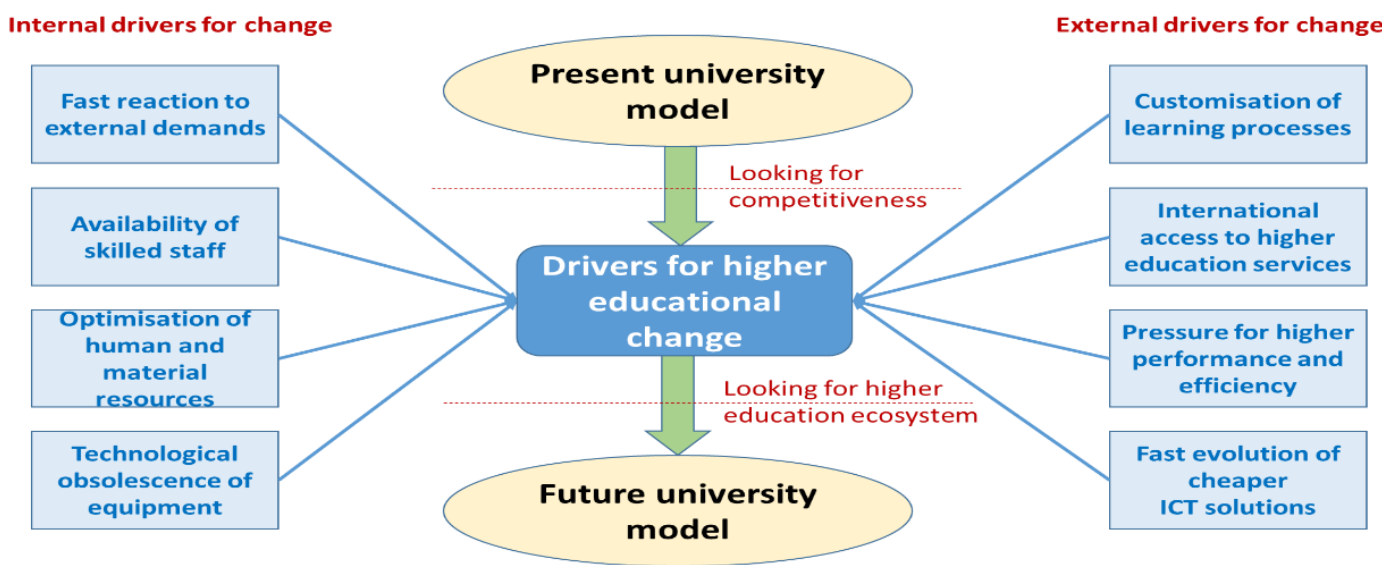

Figure 4. Drivers for higher educational change (Source: own elaboration)

Figure 4 refers to a change of university model where emphasis shifts from ensuring "competitiveness" (as an isolated goal) to create the most adequate "higher education ecosystem" (as a shared goal). Behind that approach is the recognition that other partners will be needed for one university to be globally competitive.

\subsubsection{Continuous adaptation of the academic offer}

Deep changes in firms' structure, product, services and international footprint continuously require the availability of employees with the right skills. Usually, these needs are formally or informally transmitted to universities by requesting changes in the academic offer looking for delivering graduates with the necessary skills. However, the permanent complaint to universities on the lack of response to the demands of new skills requested by industry reflects a substantial challenge for universities themselves: the necessity to modify their academic offer based on short-term industry needs or to anticipate longer-term trends even when (local) industry is not demanding it (yet). 
Specific solutions to address the risks behind this non-compatible timing perspective are needed. One of the most controversial issue is the blurring boundaries between higher education and training workforce on-the-job. Universities are committed to seek the way to better deliver on career outcomes for students by increasing the agreement with private industry for deeper integration between job skills and university curriculum for their employees.

The first item is reflected in an emerging trend where non-profit universities are contracting some services with private universities to expand their online offerings ${ }^{6}$. The intention here is to be able to offer some added-value services even if the bulk of academic degrees still follows conventional models. There is also an emerging class of companies partnering with universities for what is being termed "continuing education program management", mainly related to digital economy sector where market demand is higher, and experimentation widely accepted by stakeholders ${ }^{7}$. This approach also derives in potential risks because reputation and visibility of public universities could be damaged if the operation delegated to external companies is not well-managed and monitored and university education quality suffers.

As an example of this process, one of the well-known on-line education platforms, edX ${ }^{8}$, is expanding its partner community - with over 130 partners including research universities in the USA like MIT, Harvard, Berkeley and Oxford and leading companies like Microsoft and Amazon Web Services. Simultaneously, several innovations in education models in partnership with other conventional universities were also promoted and recently launched by edX:

- Micro-Masters programmes, a digital-age credential to advance professionals' careers or accelerate the obtaining of a Master's degree. Partnering with companies like GE and Tech Mahindra guarantee interviews to certain learners who complete specific programs and to facilitate their hiring process.

- FULL Master's degree on edX. In partnership with Georgia Tech, edX offers a master's degree in analytics for under $\$ 10,000$.

- FULL Freshman year's worth of university credit on edX. With this approach, students do not need to fill in an application for admission, thanks to the edX Global Freshman Academy program in partnership with Arizona State University.

Even more disruptive could be soon the expansion of the emerging concept of "knowledge warranty" associated to some university degrees. The concept recalls to the idea that academic degrees will suffer from very fast knowledge obsolescence; then, graduates could require (or wish) to access to knowledge maintenance process after obtaining the academic degree. Then, universities will be pushed to offer to recent graduates (ex-alumni) some extra short courses or seminars (by free access to on-line webinars, material and face-to-face tuition) during some period, even if they are in the workplace. Instruments and tools to implement new educational services to address this challenge are still in their infancy.

\footnotetext{
${ }^{6}$ The recent purchase of for-profit Kaplan University by Purdue University is one of the clearest examples of the ascendance of service-oriented enablement businesses. Fundamentally, Purdue is acquiring what it sees as a strategically critical capability so that it can reach a new market, bringing a key aspect of its academic business into the online age. In addition, on the Kaplan side of the equation, the deal appears to be an assessment that the long-term future of building profitable businesses in education is more about servicing universities than in owning and operating them.

${ }^{7}$ For example, Trilogy Education Services (https://www.trilogyed.com/) creates and manages skills-based training programs in Web Development, Data Analytics \& Visualization, and UX/UI Design. Collectively, Trilogy, and its network of more than 20 of the world's leading universities, have unmatched visibility into the trends affecting students, employers, and universities in the Digital Economy.

${ }^{8}$ See for further details https://www.edx.org/
} 
One of the most controversial issue deriving from the above-mentioned evolution of higher education is the blurring boundaries between higher education and continuous education concepts for skilled workforce. Universities are committed to seek the way to better deliver on career outcomes for students by increasing the agreement with private industry for deeper integration between job skills and academic curriculum. In fact, the "maintenance of knowledge" could be more easily implemented through agreements with the private sector.

\subsubsection{Focus on added value activities}

Today, daily management of universities are forced to deal with many non-crucial activities to be able to run high-quality educational services. As it happens with many other public and private entities, an internal discussion about the need to concentrate efforts in "university core businesses" and to outsource other non-critical aspects has emerged many times in the field of universities' management. Part of it was done in the past by outsourcing secondary services (e.g. security, cleaning, restauration, dormitories, auditorium, maintenance, etc.) to specialised firms; however, core physical premises, key staff, labs equipment, ICT facilities, and the generation and provision of educational contents are owned and managed by universities themselves, fully convinced that quality control of education services will depend on the right and integrated management of all of them.

The current debate is focused on what of them should be considered as core competences of a public university in the near future. Is it possible to continue the streamlining process started in the past even more without putting at risk essential functionalities, reputation and visibility? What should be the consequences of this process on (public) funding, public control of educational processes, and students' or citizens' perception? Answers to these questions are controversial: they reflect ideological positions of stakeholders with respect to the role to be played by (public) universities in society and what should be responsibilities taken by governments.

Furthermore, new technology-based approaches will continue to surface several strategic questions for universities and policy-makers. From our point of view, higher education's traditional policy and regulatory architectures must self-adapt to richer contexts where the provision of higher education services could come from several public and private actors not involved until now. As Gallagher (2017) has indicated: "In this new landscape, colleges and universities remain in the driver's seat-but they must be careful to assess and consider their core competencies. Entrepreneurs have the opportunity to open up entirely new markets by thoughtfully providing ideas and practices from the for-profit industry while aligning with academic values and working as true partners and co-developers of technology rather than in just a classic 'vendor' model."

This vision advices to put more emphasis in the creation and sustainability of strongly connected "university ecosystems" more than in isolated universities as the most appropriate way to offer attractive education systems. In this context, stakeholders involved should focus in those areas where they perform better and customers (mainly the enrolled university students but not only) will be able to receive higher quality educational services.

\subsubsection{Performance-based funding}

Recent studies (EUA, 2017) indicates that since the 2008 financial crisis, the divide between higher education systems that could increase public funding and those that were forced to reduce the level of investment is getting wider in Europe. The findings of the Public Funding Observatory Report 2017, published by the European University Association or EUA, also show that while 2012 was the year of "deepest crisis" for universities in Europe with the largest 
number of systems cutting funding, any recovery that can now be detected is slow and fragile: "only 14 systems had higher funding in 2016 than in 2008 and eight of those have a faster growth in student populations compared to the increase in funding. Nineteen systems still had lower levels of direct public funding than at the time of the financial crisis" (EUA, 2017).

Associated to the internal drivers, there is also a trend in public universities from a growing pressure for higher efficiency and performance in their operation as a basis for public funding (performance-based funding, PBF) (Debackere et al., 2018). In recent words from the European Commission's services (SWD, 2017) the situation is stated as follows:

"In recent years, there has been a general shift towards systems that pay universities based on the outputs they produce (number of graduates, number of research publications etc.), rather than purely on the basis of established costs. At the same time, a number of countries have introduced performance contracts between the state and higher education institutions which established specific targets, the achievement of which may be rewarded with funding. Outputbased funding formulas and performance agreements with funding linked are types of 'performance-based funding' (PBF)".

Most PBF schemes focus on the quality of research and its scientific impact although recently additional criteria are being used, especially in relation to societal impact. In principle, PBF schemes are backwards-looking systems for allocating funding so in practice, few of them consider potential future performance.

This trend is not only linked to public universities in order to be rewarded (or not) with additional public funds (in many cases, it is a redistribution of pre-existent resources within a group of universities); it is also related to another megatrend to convert public universities in

"sustainable" entities capable of managing efficiently public budgets and able to attract external funds.

It is worthy to mention that a large part of the open discussion around universities is framed in the USA under the "cost perspective", fuelled by the value of expensive college degrees. The problem boosted from the dramatic increase of unpaid loans for university studies and the feeling from middle-class families that this time it will be much more difficult to give their children a university education as they had in the past.

This cost-value trade-off analysis is also behind the boosted phenomena of cheaper MOOCs despite its well-known weaknesses to ensure continuity over time (statistics said that only $7 \%$ of students are finishing on-line degrees) and poor adequacy to be applied to some technical or engineering degrees where large equipment is needed, or the difficulties to address soft skills.

Anyway, many European universities are also testing the use and adequacy of on-line learning modules in combination to face-to-face models (i.e. blended learning) to be able to reduce costs, address additional demands for students' flexibility and to get the same degree of quality and performance than in the traditional education process (i.e. to get the same level of fail graduates and employment rates of graduates) (Dion et al., 2018; Pisoni et al., 2018).

\subsubsection{Embeddedness of universities in society}

From the perspective of the national and regional governments responsibility in funding public universities for their educational mission, the economic effort from citizens should be clearly compensated by delivering benefits for the whole society. In broader terms, it is also necessary to address the needs of common citizens not involved in universities' regular courses and to increase the presence and visibility of universities in society. 
The well-known pressure to enhance the interaction between research and teaching is complemented by two new drivers: to maximise "socioeconomic impact" (not necessarily at local level) and widening the "participation in community work" (moving the activity outside the university campuses). It calls for transformative, responsive, demand led actions, which do not belong to the common set of present university priorities.

Around this concept emerged the idea of the "civic university" (Goddard, 2014). The intention is to provide a theoretical model for social responsible higher education institutions engaged in the society around them (SWD, 2017). The model sees engagement with the outside world as an integral part of universities' activities by blurring the borders between universities and society. Figure 5 schematically depicts main concepts around a "civic university".

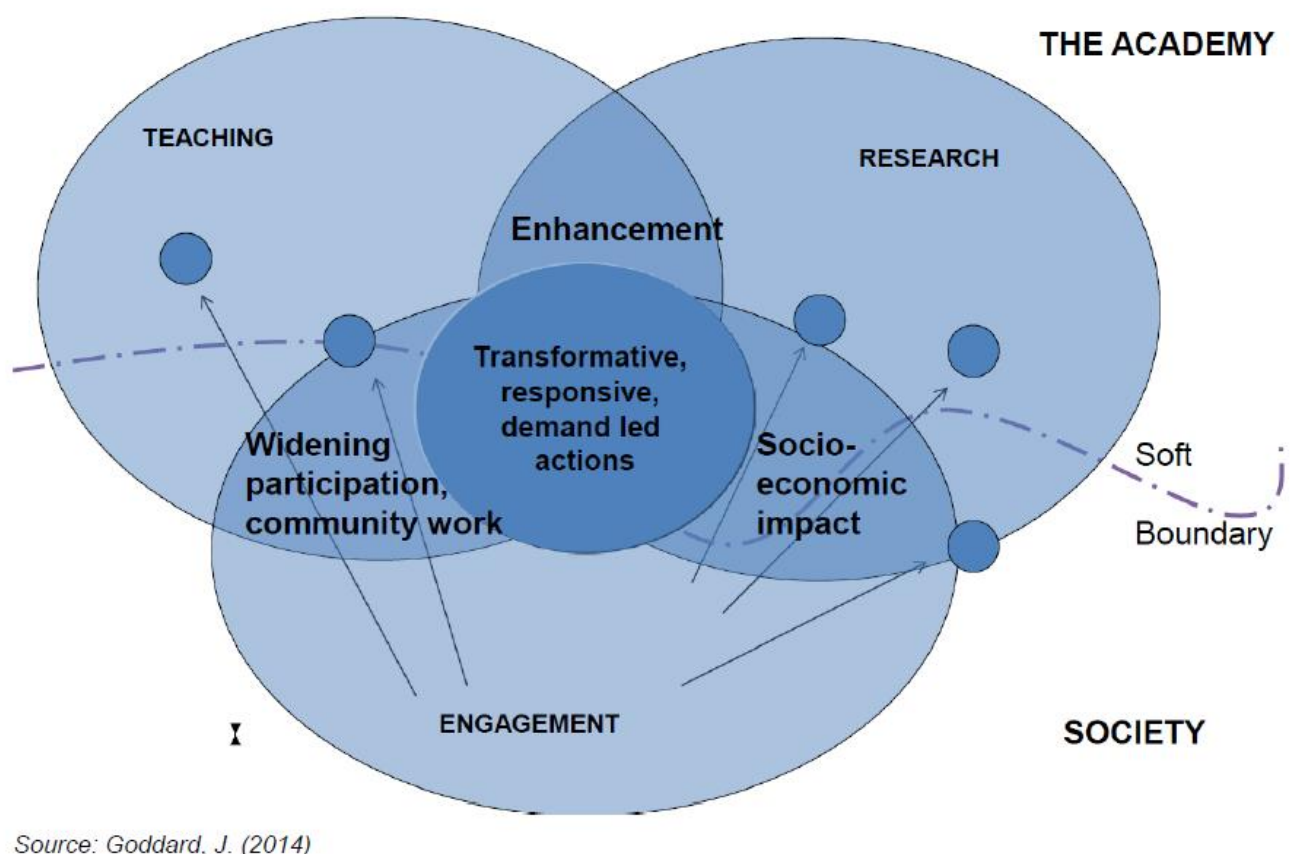

Figure 5. Concept of "civic university" (source: Goddard, 2014)

Leaders of large cities are especially motivated to find win-win links with universities located in the city to transform and make them more attractive to live, work and invest. Then, universities are perceived as key stakeholders to support the transformation of the city from several perspectives (e.g. urbanism, transportation, digitisation, environment sustainability, socioeconomic development, cross-generational diffusion of information, etc.). As an example of this process, the engagement of university students in some of these activities defined as part of their university curricula development (through agreements with universities for ECTS allocation if needed) seems a feasible approach.

\section{University as a digital "platform"}

\subsection{Rationale}

The wise combination of several technical drivers (derived from the wide availability of ICT-based solutions in the educational market and higher confidence in their advantages) and nontechnical drivers (derived from the need of optimisation of resources and deeper society 
engagement where social networks and big data analytics will play a prominent role) for the evolution of universities will make the current situation an opportunity for public universities to increase their value for further socioeconomic growth.

Under this approach, we envisage that some of the educational services offered today by universities through conventional processes will be provided as renewed "educational services accessed through sophisticated education platforms open to the cooperation with other stakeholders".

A "university education platform" is conceived in this article as a conceptual tool where a number of seamless IT-powered higher education services are smoothly provided by a set of interrelated public and private stakeholders, which are coordinated by a public university playing a key role to generate skilled high-quality professionals on behalf of society demands with loose requirements of physical and timing synchronisation.

This operational definition of "university education platform" widen the conventional approach of university activity in two main directions:

1) The need to design and provide higher education services with the deep participation and commitment of other stakeholders in the university ecosystem, and

2) The intensive use of IT solutions as a key element of the value chain to optimise resources and to be able to offer high-level customised services for students.

The "university education platform" concept is borrowed from recent developments of the "collaborative economy" (COM, 2016b; COM, 2016c) where many actors are able to create added value in a number of economic sectors by introducing deep changes in traditional valuechains through the use of digital platforms.

This "university education platform" concept cannot be confused with simply providing all higher educational activities through a digital platform. The concept of "university platform" is richer and more complex because it needs to be interpreted in a dynamic university ecosystem regardless the technology used to provide services.

Figure 6 reflects the transition process from the actual context and the future context, where the university education platform concept became a reality. The left side of figure 6 expresses the current situation where the academic offer is conceived, made public and implemented (by following the rules set-up by the governmental and regulatory context) by using the university internal structure. The right side of figure 6 depicts a more complex scenario, where the university academic offer is jointly implemented by the university with a set of partners' entities (ranging from other universities to specialised firms located anywhere). Now, the concept of "university education platform" reflects education partnership agreements where human and material resources are wisely combined in a transparent way to enrolled students. 


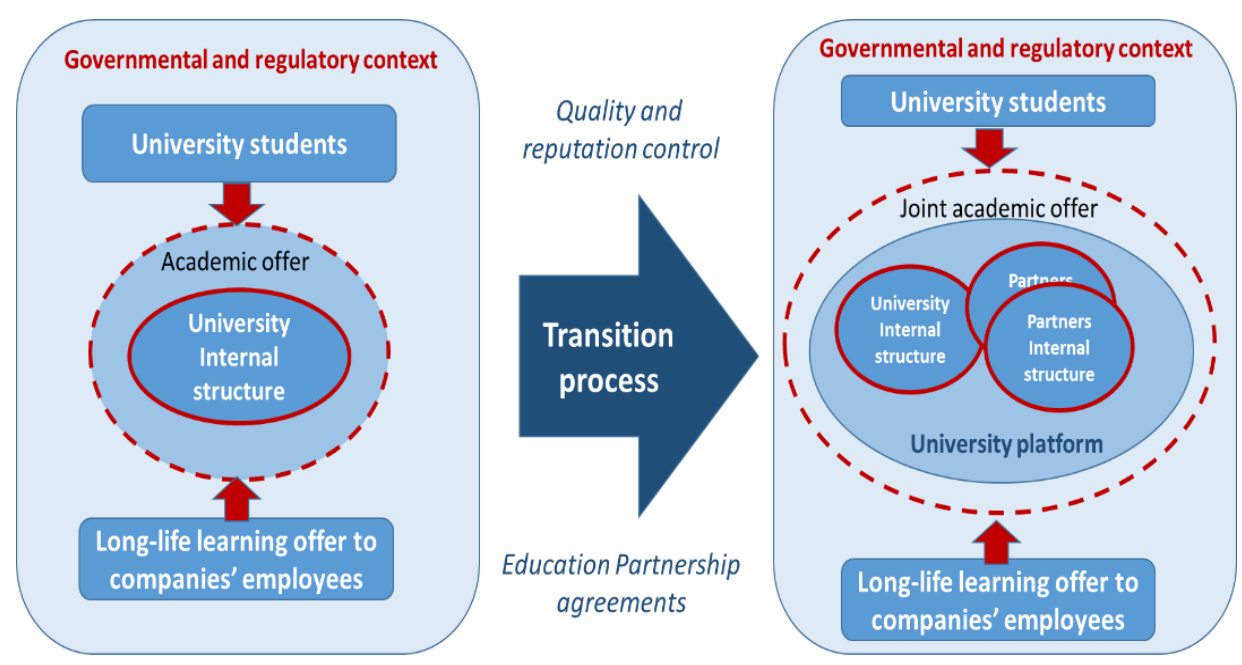

Figure 6. Transition towards a university platform concept (source: own elaboration)

Obviously, this approach implies the implementation of a sound quality and reputation control by the public university, which will keep the responsibility to grade students and it respond to that to the quality governmental agencies. Notice that this approach is compatible with double diploma models currently use when two or more universities participate in the process.

\subsection{University education platform}

The model of provision of higher educational services through a "university education platform" implies that many activities directly performed in the past by universities as part of the value chain will be moved to one shared university-education platform.

Notice that the concept of "university education platform" is not only linked to a simple ICTpowered digital platform; however, the evolution of ICT digital platforms constitute the most relevant enabler and it offers great opportunities to implement the concept in an efficient way as it will be discussed later on. Main changes with respect to the present situation of higher educational services that are powered by the use of advanced digital platforms are the following ones:

- Full adoption of digital marketing and awareness techniques. Both business schools and private universities had fully understood years ago that the use of "digital marketing" techniques constitutes a key factor to increase their attractiveness for potential students at international level. Today, the same approach is being (slowly) realised by public universities over the world where the attraction of students at local level is not guaranteed anymore (due to local or on-line competition, but also by demographic reasons).

Then, they need to increase their footprint in other regions or countries to ensure full enrolment in all offered degrees. This approach is not only based on web 2.0 sites but also full use of social networks to be able to convey personalised messages to prospective students after careful customer segmentation process and big data analytics to process current date with historical trends for fine tuning. This activity will deserve the allocation of substantial funds and efforts with skills, which are not easily found in traditional universities.

- Full digitisation of the enrolment and follow-up process. Universities made efforts in the past to reduce clerical work by developing (or purchasing) ad hoc customer relationship management (CRM) software packages, and full e-administration solutions feeding up a broad range of mobile services. Then, the starting point is better although the integration of a large set of independent software packages or applications is still a problem. Nevertheless, 
the maintenance of proprietary systems became a source of heavy legacy problems to migrate to new IT systems; then the trend to find integrated common (shared) solutions is increasing although no common university IT reference architecture has been adopted.

The use by students of device-independent access to all types of administrative procedures and personal data (even their grading marks on real time!) is becoming part of common services offered by universities. The emerging use of Al-based personal assistants for enrolled students will offer them another level of personalised support not available in the past, and universities can also support their strategic decision-making by extracting behavioural patterns from big data analytics.

- Crowdfunding platform to increase external funding. An additional issue also borrowed from the collaborative economy field is the use of "embedded crowdfunding platforms" in order to get additional funds to support education costs (e.g. student's fellowships). In the USA where tuition costs could be very expensive, this approach is getting momentum ${ }^{9}$. European universities are far from promoting the use of crowdfunding in practice while tuition fees remain very low.

Another extra value of this kind of embedded platform came from its role to increase the engagement in society where open activities of the university could be also promoted through small economic contributions from citizens (even from ex alumni networks). The combination with other mechanisms based on social networks will also promote better knowledge of the activity and strengthening the role played by universities in society.

When applied to public universities this approach could require specific regulations and rewarding to taxes schemes.

- Full adoption of blended learning models. Universities are compelled to explore innovative learning models to offer customised services and higher efficiency for teaching activities by using pre-defined modules from their partners' networks (León, Leceta and Tejero, 2016).

Then, face-to-face lectures (initially in university premises but in the future also in partners' premises) are combined with on-line access to educational material probably shared by university networks to save efforts. The case of EIT Digital Master School ${ }^{10}$ is an example in this process where on-line material is made available in a common repository, where partners' universities can extract and incorporate in their own ad hoc courses, the selected on-line material adequate to their needs.

- Individual grading based on customisation and gamification of students' knowledge assessment where both timing and procedures are adapted to individual needs and are desynchronised from general scheduling.

This approach was very difficult to implement in the past for large number of students enrolled in the same course where grading synchronisation was the norm. However, today is becoming a feasible solution provided by advanced IT systems and additional flexibility

\footnotetext{
${ }^{9} \mathrm{U}$ Fund, University High School's annual fund (https://www.universityhighschool.org/giving/the-ufund/) is the single most important source of yearly fundraising income to make up the difference between tuition and the actual cost of the education provided.

${ }^{10}$ See for further details https://masterschool.eitdigital.eu/
} 
can be offered to students. The full deployment of this approach could require regulatory changes to be able to coexist with conventional grading systems.

Several of the above-mentioned activities were embedded in figure 6 under the term "university platform" by assuming that students will not be necessarily aware of some of the partnerships used to provide the education processes. The implementation of this approach dramatically benefits for the deployment of one or more digital platforms to provide access to data repository and analytics, uniform user interfaces, customisation and individual tracking of learning process.

Inside the "university education platform" several campus activities (both physically and on-line) are included. In this context, it is worthy to analyse the value of keeping physical university campuses, which have constituted the most visible element of a traditional university. It is possible to think that the model presented above could make them unnecessary relics of the past (even motivated by economic reasons in owned state management).

Within the umbrella of "university campuses", universities usually provide facilities for developing a large number of activities: project-based learning between groups of students, free exchange of ideas among students and faculties outside curricular-based activities, promotion of debates and rich cultural life (in crucial years where the personality of students is being shaping), but also to be able to carry out other additional activities like business incubators, students' competitions, open days for citizens' visits, etc. Furthermore, in a model where partnerships become a driving force, campuses constitute a common space to be shared with other partners to increase mutual commitment and alignment. Then, physical presence of joint labs, university-industry chairs, living labs, demonstration or pilots with industry partners, etc. also constitute added-value activities for interdisciplinary and cross-cutting university education approaches. The difference in the case of university platform-based model is that campuses activities are not necessarily restricted to university premises because the concept of "campus" refers to a shared space with other partners.

Today, very large innovative companies located in the Silicon Valley (see Google or Facebook cases) are creating their own "corporate campuses" by mimicking the same approach that universities were using for decades: a shared space where students and faculties live in order to facilitate knowledge generation and transmission. The idea of creating a "corporate campus" (not only corporate physical premises as usual) came because industry leaders trust in a model where employees can learn from others, exchange ideas, and to increase creativity, if possible, with other entities... as universities are doing.

The right approach is not to remove university campuses or to move them far away but to convert them in "smarter campuses" fully embedded in society. If advanced IT solutions could also provide a sense of "virtual proximity" to other external spaces (advances from virtual/augmented reality will play a role in it), campuses can extend their footprint to other places over the world where partners are located by contributing to international higher education goals. It is from this point of view where the interaction with the concept of "smart campus" emerges.

Table 1 summarises the main differences between the traditional model of universities and the "platform-based" model described above.

\begin{tabular}{|c|l|l|}
\hline \multicolumn{1}{|c|}{ Phase } & \multicolumn{1}{|c|}{ Traditional model } & \multicolumn{1}{c|}{ Platform-based model } \\
\hline Academic offer & $\begin{array}{l}\text { Defined by public universities by } \\
\text { following governmental rules and } \\
\text { hard guidelines (e.g. structure, }\end{array}$ & $\begin{array}{l}\text { Defined by universities by following } \\
\text { governmental rules and guidelines as usual. } \\
\text { New features characterised by: }\end{array}$ \\
\hline
\end{tabular}




\begin{tabular}{|c|c|c|}
\hline & $\begin{array}{l}\text { minimum number of enrolled } \\
\text { students, assessment and budget } \\
\text { constraints) to get the approval of } \\
\text { degrees. } \\
\text { 1. Low level of flexibility for } \\
\text { customisation to individual needs. } \\
\text { 2. Based on full academic years ( } 3+2 \\
\text { or } 4+1 \text { models). } \\
\text { 3. Other degrees only recognised by } \\
\text { universities. }\end{array}$ & $\begin{array}{l}\text { 1. Micro-courses components. } \\
\text { 2. Higher flexibility to create personalised } \\
\text { curricula for individual students. } \\
\text { 3. Cross-university degrees with flexible } \\
\text { curricula. } \\
\text { 4. Project-based and blended learning. } \\
\text { 5. Company internships during the studies } \\
\text { (not necessarily linked to full academic } \\
\text { courses but by short and intensive } \\
\text { seminars). }\end{array}$ \\
\hline $\begin{array}{l}\text { Marketing and } \\
\text { awareness }\end{array}$ & $\begin{array}{l}\text { Passive approach for quasi-captive } \\
\text { local students (strong dependency } \\
\text { on territory). } \\
\text { Reputation and interest in university } \\
\text { rankings to attract foreign students. }\end{array}$ & $\begin{array}{l}\text { Aggressive targeted worldwide marketing. } \\
\text { Intensive use of social networks, } 2.0 \text { web- } \\
\text { based tools. } \\
\text { Reputation linked to comprehensive or } \\
\text { specialised rankings. }\end{array}$ \\
\hline $\begin{array}{l}\text { Students' } \\
\text { decision }\end{array}$ & $\begin{array}{l}\text { Entry qualifications defined by } \\
\text { number of entry students. } \\
\text { Open information for pre-selected } \\
\text { degrees provided by universities } \\
\text { (web-based). } \\
\text { Moderate impact of rankings. }\end{array}$ & $\begin{array}{l}\text { It will continue an individual decision but } \\
\text { increasingly supported by: } \\
\text { 1. Use of social networks to receive } \\
\text { immediate feedback. } \\
\text { 2. Al students' assistants. } \\
\text { 3. Specialised platforms for smart } \\
\text { comparison (i.e. through specific university } \\
\text { recommenders). } \\
\text { 4. Customised rankings. } \\
\text { 5. Timing knowledge of entry qualifications. }\end{array}$ \\
\hline $\begin{array}{l}\text { Selection and } \\
\text { enrolment }\end{array}$ & $\begin{array}{l}\text { Performed by universities } \\
\text { themselves. Based on the marks } \\
\text { obtained by students in high school } \\
\text { and specific exams to enter to the } \\
\text { university. }\end{array}$ & $\begin{array}{l}\text { Use of data analytics and Al assistants to } \\
\text { support universities in the selection } \\
\text { process. } \\
\text { Possible use of external partners to } \\
\text { outsource part of these processes. }\end{array}$ \\
\hline $\begin{array}{l}\text { Teaching and } \\
\text { learning }\end{array}$ & $\begin{array}{l}\text { Face to face complemented by some } \\
\text { on-line modules and project-based } \\
\text { learning. } \\
\text { Limited individual tuitions (under } \\
\text { request). }\end{array}$ & $\begin{array}{l}\text { Blended models where face-to-face is } \\
\text { dramatically reduced. } \\
\text { Personalised on-line modules (or micro- } \\
\text { modules). } \\
\text { Video-calls tuition. }\end{array}$ \\
\hline Grading & $\begin{array}{l}\text { Based on pre-scheduled individual } \\
\text { exams (with increased emphasis on } \\
\text { continuous evaluation) and quality of } \\
\text { assignments project-based activities. }\end{array}$ & $\begin{array}{l}\text { Increasing use of gamification techniques to } \\
\text { assess the students' progress. } \\
\text { Knowledge certification at any moment } \\
\text { during the academic year (based on ECTS } \\
\text { fulfilment). }\end{array}$ \\
\hline Campus activity & $\begin{array}{l}\text { All activities are conducted in the } \\
\text { university premises. } \\
\text { If possible, students' dormitories are } \\
\text { located in the campus. }\end{array}$ & $\begin{array}{l}\text { Only some activities where face to face } \\
\text { interaction is essential for the learning } \\
\text { process will use the campus facilities. } \\
\text { Concentration of physical activities in } \\
\text { shared spaces with other partners. }\end{array}$ \\
\hline Partnering & $\begin{array}{l}\text { Educational public or private } \\
\text { partners are not essential } \\
\text { components of the university } \\
\text { ecosystem. } \\
\text { Universities perform all basic } \\
\text { activities with its own resources and } \\
\text { in their own premises. }\end{array}$ & $\begin{array}{l}\text { Both public and private partners play a role } \\
\text { in providing educational services. Some key } \\
\text { aspects are: } \\
\text { 1. Industry internships are common and } \\
\text { compulsory to get a degree. } \\
\text { 2. Shared facilities and equipment. } \\
\text { 3. Use of partners' premises. } \\
\text { 4. Involvement of external instructors and } \\
\text { mentors. } \\
\text { 5. Deeper engagement with society. } \\
\text { 6. Common governance schemes. }\end{array}$ \\
\hline
\end{tabular}




\begin{tabular}{|l|l|l|}
\hline & $\begin{array}{l}\text { Governance is mainly a university } \\
\text { concern based on their own boards } \\
\text { and, if needed, advisory committees. }\end{array}$ & 7. External quality assurance. \\
\hline $\begin{array}{l}\text { Funding } \\
\text { platforms for } \\
\text { education }\end{array}$ & $\begin{array}{l}\text { Funding is provided by governments. } \\
\text { Fixed tuition fees set-up by } \\
\text { governments (per ECTS). } \\
\text { Small percentage from education } \\
\text { services offered to firms. }\end{array}$ & $\begin{array}{l}\text { Funding only partly provided by } \\
\text { national/regional governments. } \\
\text { Crowdfunding platforms (e.g. for ex alumni } \\
\text { or industry partners). }\end{array}$ \\
\hline
\end{tabular}

Table 1. How the traditional value-chain model for public universities is changing (source: own elaboration)

In parallel, universities should decide if they are ready to provide all these elements by themselves or if it were better to trust on external partner entities (even on other universities' resources), which can provide some of the mentioned educational services.

A key issue behind this transformation process is to decide at what extent one pre-existent public university should move core educational processes to the associated partner ecosystem while preserving its role and visibility. In other terms, what should be the most adequate balance and consequences for the long-term sustainability of the added-value offered by the university to students and society-at-large?

The evolution of the model is to give additional emphasis to the education partner ecosystem instead of relying exclusively on internal resources. Figure 7 presents two options ( $A$ and $B$ ), which could be also understood as phases to be implemented over time. Phase A reflects nearterm changes that can be progressively introduced without implementing deep changes in structure and governance. Phase B assumes the implementation of a disruptive model where the "partner ecosystem" acquires much more relevance in governance and implementation.

\section{Phase A: extension of current model}

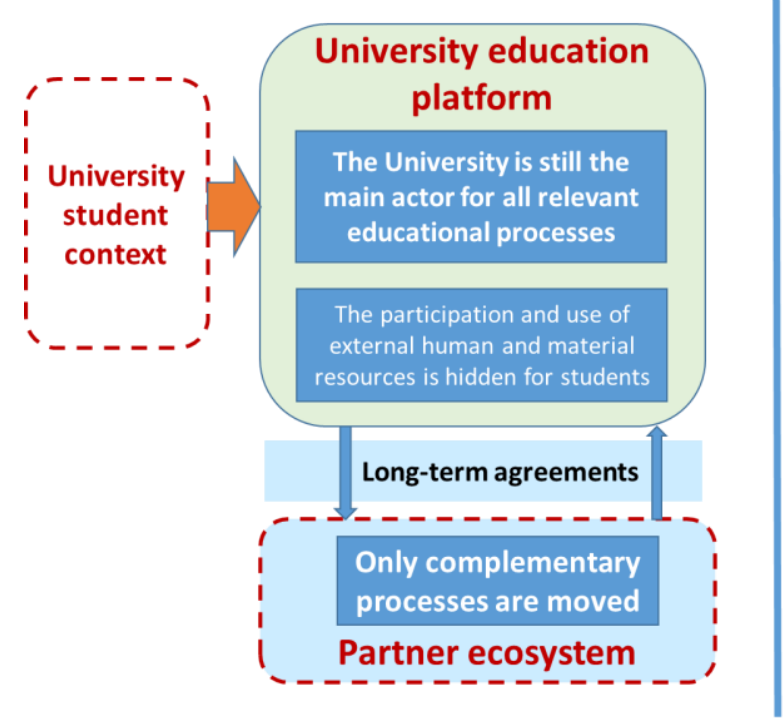

\section{Phase B: disruption of current model}

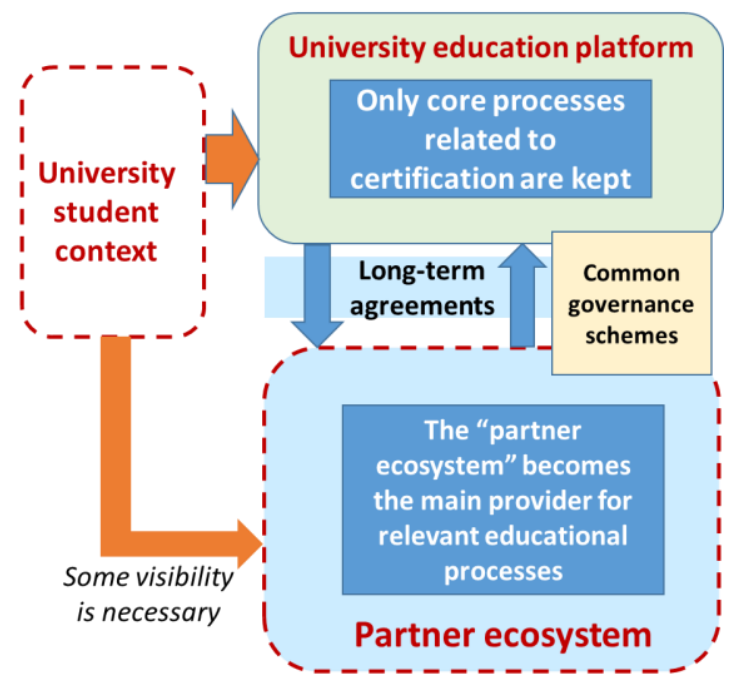

Figure 7. Relationships between the "university platform" and its partner ecosystem (Source: own elaboration)

\footnotetext{
${ }^{11}$ Resources for research and innovation are not included in the table, which is focused on the education mission of universities.
} 
Phase A could be understood as an evolutionary transformation of present universities. Only some back-office processes are delegated to partners under service contracts. Then, governance and visibility to students' context remains under the responsibility of the university. Some of the migrated services could be: use of external premises (e.g. rented buildings or shared equipment), IT services (e.g. cloud-based access, hosting, management of social networks, big data analytics), and limited use of external experts.

Phase B could be understood as a revolutionary transformation of present universities. In this case, many educational activities are migrated although the university keeps the control of "students' knowledge certification". In this phase, the governance will evolve towards a "shared governance model" with stronger commitments from partners. Some additional services on top of the phase A services could be: extensive use of external contents and experts, emphasis on course coordination instead of course implementation, permanent use of partners' facilities, larger visibility of partners to enrolled students, set-up of joint complex governance schemes, stronger economic commitments from partners (joint risk schemes).

Phase B also reaffirms the concept of "university education platform" as an educational model where emphasis is placed on the benefits for students regardless the ownership of contents, payroll or equipment. In this case, the partner ecosystem will be more visible to students (and probably to administrations) and the responsibility of the quality process is shared amongst partners. Anyway, the university still keeps control of the grading process and assure the quality of the learning process.

Obviously, intermediate situations could be found in practice where specific university partner ecosystem models should be adapted to national/regional regulations and context. Afterwards, both $A$ and $B$ models can coexist for specific degrees in the same university ${ }^{12}$.

Figure 8 depicts a complementary and restricted view of figures 7 where a number of potential stakeholders as part of the partner ecosystem have been identified. The figure also represents an intermediate case between phase $A$ and $B$ where some selected processes were migrated to the university partner ecosystem. Notice that data repository can be also migrated.

\footnotetext{
12 Probably, it will be the common case for comprehensive universities, because the type of partner ecosystem to be built up and the internal mentality of faculties and university leaders involved could be very different from one domain to another and it takes time. Do not forget that the decision to move one educational service to the partners' area implied the full trust on the quality performance of the service, because the university will remain as the final responsible for quality (and it will suffer external evaluation from governments).
} 


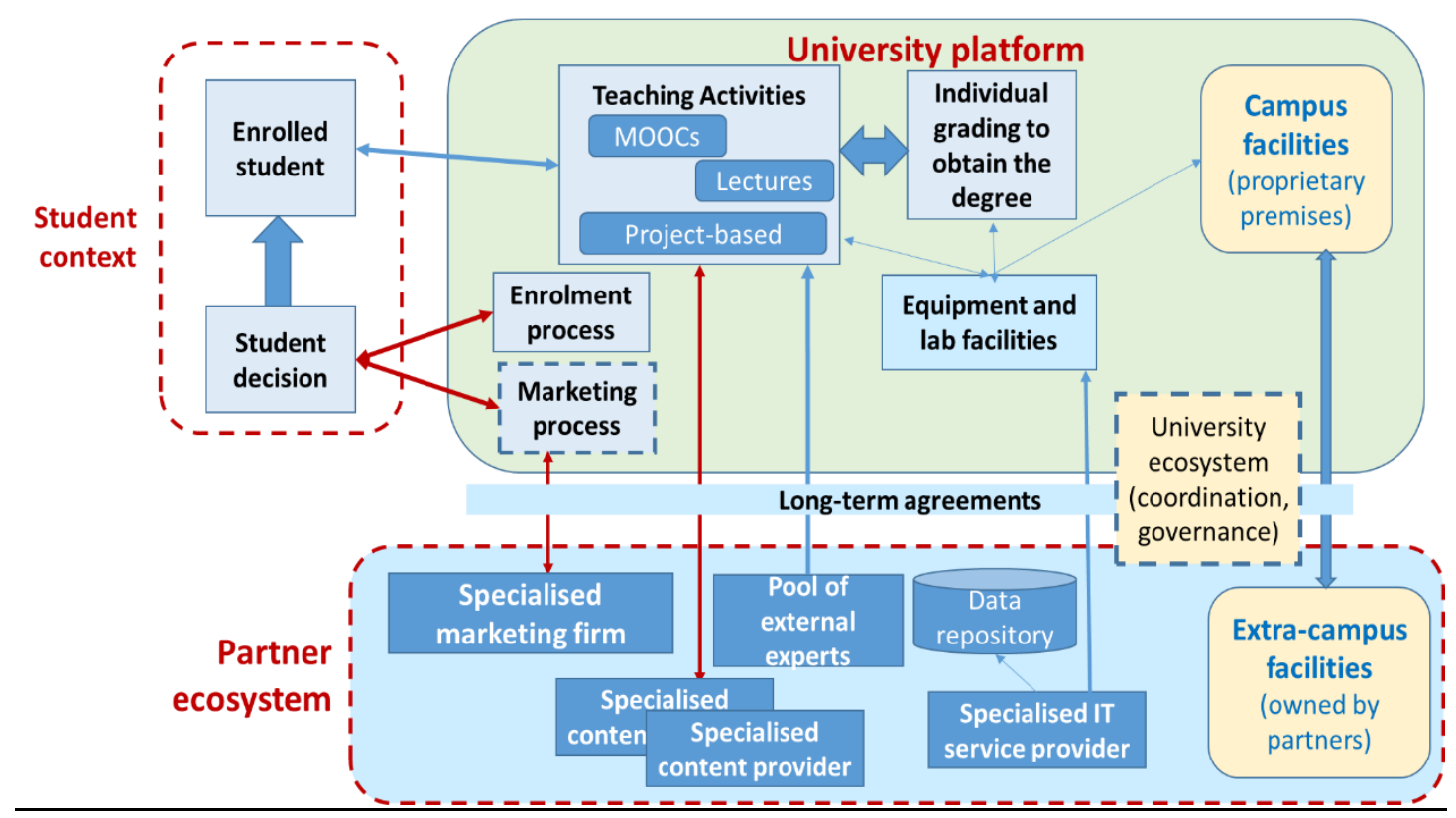

Figure 8. Putting the university partner ecosystem at work (source: own elaboration)

Data repository is usually an internal component not accessible by non-registered students. This approach could change if the university adopts a "market place" concept of platform where educational components are put at disposal of students, which can retrieve them with some revenues model (e.g. subscription or downloading fee). Here, the university could guide or influence but not impose what should be the most appropriate modules. At the end, the control for grading is based on the assessment process of individual knowledge.

We are well aware that the implementation of this model presents some deep consequences. Some of the identified open challenges are as follows:

- Impact on contents creation. If some of the educational material of courses (i.e. learning modules) included in the curriculum are provided by external partners (e.g. from other universities or private firms belonging to the partner ecosystem) or event after buying them in the educational market some questions are open:

What should be the mechanism to select and control the quality and adequacy of that content?

What is the minimum percentage of proprietary contents necessary to preserve the university identity with respect to the external world?

What are the consequences with respect to IPRs if some material is modified or extended (e.g. who is the owner)?

Is it possible to extend the "chair freedom" to this case?

- Faculties' composition. Under the university education platform concept, public universities should devote institutional efforts to find the right external experts to complement their internal staff profiles by keeping alive the possibility to develop the professional career for their own faculties' member.

In fact, this is a common practice for graduate studies ${ }^{13}$ in many universities but less common in undergraduate studies. We envisage the spreading out of that approach to

${ }^{13}$ In Spain, it is common to find university regulations where up to $30 \%$ of faculties in master's degrees could be allocated to external experts (from industry or public administrations); they also increase the attractiveness of those degrees when employability is a must. Apart from that, visitors' professors are always welcomed even when they are marginal and limited to sabbatical periods. 
undergraduate courses and to progressively break internal barriers to accept part-time or invited speakers. Again, open questions are related to the wise balance between permanent faculties and external experts to consolidate university reputation and homogeneity. Are the commitments of teachers at the individual level enough or do they be embedded in the partnership agreements at the institutional level? Furthermore, for public universities it requires a delicate balance with the teaching freedom principle.

- Use of physical premises. For some studies (e.g. in science and engineering curricula) the access to advanced facilities and equipment is in the basis of the quality of education. Project-based learning strongly depends on it. Nevertheless, as indicated above budgetary constraints have motivated public universities to find alternative solutions.

If the education ecosystem (partnership model) is fully accepted, why not to rely on equipment located in partners' premises and not in university premises? What are the consequences on the visibility and reputation of university? Do they affect the employability of graduates?

- Continuous grading. The full deployment of the university education platform model and the use of sophisticated IT tools can provide the basis for implementing more innovative "continuous grading" approaches not synchronised to conventional academic years where students can decide to present themselves to the grading exams when they feel ready or when they have passed the minimum set of compulsory activities.

Here, the introduction of IT-based gamification rewarding systems to reduce "students' abandons" (borrowed from experiences in gamification outside the university world) could be automatically provided by a digital platform for a number of subjects included in the academic curriculum. This is also a key issue for graduate students.

- Long-term stable partnerships. The deployment of the university platform model requires to set-up a specific set of partnerships with public and private entities for long periods of time linked to the implementation of some university degrees (usually, five years is the minimum period to ensure that the degree is fully implemented).

These partnerships could assume economic commitments from both sides and also the distribution of profits, if any. This issue introduces a higher complexity degree in the relationships between partners, but experiences can be borrowed from other domains.

- Internationalisation. The platform model as presented in this section has not explicitly addressed the internationalisation issue as a driver. Nevertheless, it is embedded in many of the model's components. Digital platforms try to attract customers from everywhere; it also happens in higher education platforms ${ }^{14}$.

If students and faculties/experts should be attracted to the university it requires effort and experience which could be delegated to "brokers" linked to the university; if the use of blended learning models is widening, universities will need also to work with content providers from other places or countries to get agreements to be able to adapt and use them for their own purposes.

- Joint governance. For some committed partners the only way to accept risks is to become part of the governance system and control the use of their contributions. It implies that universities should create common governance spaces not only through specific bilateral

\footnotetext{
${ }^{14}$ The importance of education as an international or globalised form of trade is apparent in its inclusion in the activities of the World Trade Organisation (WTO). Particularly in its inclusion in the General Agreement on Trade and Services as a special type of service (GATS) (WTO, 1995). This approach has been strongly criticized in the past but is penetrating in many universities over the world.
} 
agreements but also by working side-to-side with governments to adapt the current legislation to facilitate partners' involvement.

Once the university platform concept is accepted by universities and public administrations the whole transformation process of European universities could be facilitated if specific open "information technology platforms" where designed for that mission. However, technical platforms for higher education in Europe will need to enable great diversity to accommodate very different contexts. Diversity will occur in terms of delivery models and blending with personalised self-services.

Disruptive platforms will also need to enable seamless integration among cooperating providers of the various components of a solution - meaning close partnership among institutions as well as innovative learning tools.

\section{Conclusions and inputs for further discussion}

The main objective of this paper is to serve as a document for the debate on university policies and strategies towards the future, focusing on technology as a dynamic element for change. In concrete, this article has presented a feasible scenario of evolution of European public universities within the digital economy, which is seen as a necessary step to address current challenges and to keep the value and prominent role of public universities in a digitised society.

If IT technology for educational processes will continue its maturation process in the near-future, if experts and educational contents we need to satisfy the demands of our students will be accessed regardless the location, if economic pressures to break facilities' obsolescence with restricted budgets is growing up,... and money could be found outside, it is time to conceive innovative approaches to university evolution.

The concept of "university platform ecosystem" presented and developed in this document is a potential answer to these challenges. We are well-aware that internal barriers still exist, and they will be even stronger the near future if the evolution forces universities to move towards the deployment of the platform concept in short periods of time. At what extent university staff will become deeply committed to a "loose institution"? ${ }^{15}$

This is not a surprising fact. As Kennedy recently wrote (Kennedy at al., 2016): "There are also internal forces at work that limit reform and innovation. The principal one is that, unlike most for-profit corporations, where the workforce is controlled by management, in higher education the workers (i.e., professors) largely control the means of production. In this case, management (e.g., chancellors, presidents, provosts) has limited ability to change work organization, restructure departments, change pedagogy, and make other changes".

Even when this article was focused on the education mission of public universities, the consequences cannot be isolated from other missions like research and innovation support. At the end, it implies to conduct deep "structural reforms" (OECD, 2012; ULAB, 2014; OECD, 2017) with consequences for the whole university. Some authors recently spoke about the "time of disruption" for universities (Abel, 2017; Davis, 2017; Driessen, 2017) thinking in the creative destruction of universities as the only way to survive on the future.

The following sentence extracted from Christensen and Eyring (2011) is an example of this movement: "In time, the new institutions will cultivate demand for their products, improve

\footnotetext{
${ }^{15}$ Academia is strongly driven by the construction of individual academic identities and reputations within groups of academic peers. Those reputations are associated with that of their institution (Marshall, 2018).
} 
quality and displace the older institutions - which did not change fast enough. This happens in Silicon Valley, and it will soon happen to campuses across America". The reasoning behind means that universities will disappear as we understand them today in the same way that other servicebased sectors are doing (see the evolution of banking or retail sector); however, six years later the work of Christensen and Eyring was published, the pace of universities' changes seems slower than assumed, and universities are still there... more or less in the same way.

We also agree on other scholars having a more critical view on the (over-used) application of the concept of "disruption to education". Johan Need (2017), from the University of Virginia's Institute for Advanced Studies in Culture said: "What makes such reforms so hard to resist is the presumption that the world is moving too fast to take stock. But is this true? Is the world changing so fast that all the things colleges and universities are supposed to do and have done have been rendered irrelevant? Are the forces of disruption really that powerful?"

Nevertheless, disruptive structural models are gaining momentum in new universities (where legacy structures and internal reactions are less relevant) to consider the university as a "container" or "platform" to provide the context (adequate space, equipment, administrative support \& interaction) where professors (or groups of) proactively perform its activity looking for resources and with full responsibility on their activity; in fact, they act as "institutional-startups" and the whole university is behaving as "incubator").

The effort made by the EU to mobilise universities in new shared governance structures (even by accelerating their evolution through specific calls for funding ${ }^{16}$ ) is becoming deeper with the launching of Erasmus+ - Key Action 2 - European Universities. This action "aims to encourage the emergence by 2024 of some twenty 'European Universities', consisting of bottom-up networks of universities across the EU which will enable students to obtain a degree by combining studies in several EU countries and contribute to the international competitiveness of European universities". It is too early to assess the impact, but the way is open.

True challenges are there out, and this is time for universities to launch wide institution-based debates to identify new challenges, opportunities, and analysis of solutions or approaches pursued by others. Based on that public universities need to explore the feasibility of the prioritised ones, to perform "controlled experiments", to analyse results, to take stock of them and to debate on the experience, and then, to implement the most adequate ones, and to setup some indicators to track progress. And we (European public universities) should start very soon (many others are in the way) by recognizing that we will need to select and convince committed partners for this journey because it is not an easy trip to the future to walk alone.

\section{References}

1. Abel, R. (2015). What is disruptive innovation in education? IMS Global Learning Consortium. Retrieved from http://www.imsglobal.org/article/what-disruptive-innovation-education

2. Aronowitz, S. (2000). The knowledge factory: Dismantling the corporate university and creating true higher learning. Beacon Press.

3. Bauer, J. M. (2014). Platforms, systems competition, and innovation: Reassessing the foundations of communications policy. Telecommunications Policy, 38(8-9), 662-673.

4. Christensen, C. M., \& Eyring, H. J. (2011). The innovative university: Changing the DNA of higher education from the inside out. John Wiley \& Sons.

\footnotetext{
${ }^{16}$ See https://eacea.ec.europa.eu/erasmus-plus/news/call-for-proposals-the-european-universities en
} 
5. COM (2000). Towards a European Research Area. Communication of the European Commission to the European Parliament, the Council, the European Economic and Social Committee and the Committee of the Regions. $\operatorname{COM}(2000) 6$ Final. January 2000. Retrieved from http://www.aic.lv/ace/ace disk/Bologna/contrib/EU/Toward EResArea.pdf

6. COM (2013). Report to the European Commission on improving the quality of teaching and learning in Europe's higher education institutions. High Level Group on the Modernisation of Higher Education. June 2013. Retrieved from http://ec.europa.eu/dgs/education culture/repository/education/library/reports/moderni sation en.pdf

7. COM (2014). European Commission: "The EU explained: Digital agenda for Europe". Directorate-General for Communication Citizens information 1049 Brussels BELGIUM. ISBN 978-92-79-41904-1 doi:10.2775/41229 European Union 2014. Retrieved from https://eige.europa.eu/resources/digital agenda en.pdf

8. COM (2016a). European Commission: "A new skills agenda for Europe. Working together for strengthen human capital, employability and competitiveness". Communication of the Commission to the European Parliament, the Council, the European Economic and Social Committee and the Committee of the Regions. COM (2016) 381 final. 10 June 2016. Retrieved from https://ec.europa.eu/transparency/regdoc/rep/1/2016/EN/1-2016-381EN-F1-1.PDF

9. COM (2016b). European Commission. "European agenda for the collaborative economy". Supporting analysis commission staff working document accompanying the document Communication from the Commission to the European Parliament, the Council, the European Economic and Social Committee and the Committee of the Regions - "A European agenda for the collaborative economy". Technical Report, European Commission. Regions. Brussels, 2.6.2016 SWD(2016) 184 final, 2016.

10. COM (2016c). European Commission. "Online platforms and the digital single market opportunities and challenges for Europe". Technical report, European Commission, 2016.

11. COM (2018). European Commission. Proposal for a Council Recommendation on key competences for life-long learning. $\operatorname{COM(2018)~} 24$ Final. 17 January 2018. Retrieved from https://ec.europa.eu/education/sites/education/files/recommendation-key-competenceslifelong-learning.pdf

12. Davis, G. (2017). The Creative Disruption of Higher Ed. The University of Melbourne. Retrieved from https://pursuit.unimelb.edu.au/articles/the-creative-disruption-of-higher$\underline{\text { ed }}$

13. Dealtry, R. (2017). The Future of Corporate Universities: How Your Company Can Benefit from Value and Performance-Driven Organisational Development. Emerald Publishing Limited.

14. Debackere, K., Arnold, E., Sivertsen, G., Spaapen, J., \& Sturn, D. (2018). Performance-based funding of university research: Summary Report. Luxembourg: Publications Office of the European Union. Retrieved from https://doi.org/10.2777/047514

15. Delgado, L. (2017). Campus de Excelencia Internacional. Hacia una reforma estructural del Sistema Universitario Español. La Cuestión Universitaria, (9), 46-59.

16. Delgado, L., \& León, G. (2015). Strategic aggregation of Universities in Spain: The Spanish program international campus of excellence and the experience of the Technical University of Madrid. In Mergers and alliances in higher education (pp. 243-272). Springer, Cham. 
17. Dion, G., Dalle, J.M., Renouard, F., Guseva, Y., León, G., Marchese, M., Mutanen, O.P., Pina Stranger, A., Pisoni, G., Stoycheva, M., Tejero, A. \& Vendel, M. (2018): Change Management: Blended Learning Adoption in a Large Network of European Universities. ICEL. Paper presented at 13th International Conference on e-learning 2018. South Africa. https://www.eitdigital.eu/fileadmin/files/2018/newsroom/Academy/ICEL Paper Final Di on Dalle Renouard et al-2.pdf

18. Driessen, B. (2017). Three ways education is being disrupted by digital technology. Pwc digital pulse. $17 \mathrm{Jul}$ 2017. Retrieved from https://www. digitalpulse.pwc.com.au/three-wayseducation-disruption-digital-technology

19. EIT (2008). Regulation of the European Parliament and of the Council (EC) No 294/2008 establishing the European Institute of Innovation and Technology. Official Journal of the European Union L 97/1. Retrieved from http://eurlex.europa.eu/LexUriServ/LexUriServ.do?uri=OJ:L:2008:097:0001:0012:EN:PDF

20. EIT Digital (2017a). Driving's Europe Digital Transformation. Strategic Innovation Agenda 2017-2019. Retrieved from https://www.eitdigital.eu/fileadmin/files/2016/publications/EIT-Digital SIA 2017-19.pdf

21. EIT Digital (2017b). Micro-masters in the EIT Digital Coursera offer. University of Eindhoven. 2017

22. EHEA (1999). The Bologna Declaration on the European space for higher education: an explanation. Confederation of EU Rectors' Conferences and the Association of European Universities (CRE). Retrieved from https://web.archive.org/web/20080411015353/http://ec.europa.eu/education/policies/e duc/bologna/bologna.pdf

23. Engelbert, N. (2017). Building relationships across the entire student life-cycle. The transformational Journey to Campus-wide CRM. Ovum Technology. 28 September 2017.

24. Eurydice (2017). Modernisation of Higher Education in Europe: Academic Staff. Eurydice Report. 2017. EC-01-17-491-EN-N Education, Audio-visual and Culture Executive Agency, June 2017. ISBN 978-92-9492-510-7 doi: 10.2797/408169. Retrieved from https://webgate.ec.europa.eu/fpfis/mwikis/eurydice/images/3/3c/209 Academic Staff 2 017.pdf

25. EU (2013). Regulation of the European Parliament and of the Council establishing Horizon 2020 - the Framework Programme for Research and Innovation (2014-2020) and repealing Decision No 1982/2006/EC. Brussels, 22 November 2013. Retrieved from https://eurlex.europa.eu/LexUriServ/LexUriServ.do?uri=OJ:L:2013:347:0104:0173:EN:PDF

26. Pruvot E.B., Estermann T., \& Kupriyanova V. (2017). Public Funding Observatory Report 2017. European University Association. December 2017. Retrieved from http://eua.be/Libraries/governance-autonomy-funding/eua-pfo-report-december2017. pdf?sfvrsn $=2 \& u t m$ source $=$ Press + List $\& u t m$ campaign $=08$ b8ba2ffa-Press-ReleasePFO-12-12-2017\&utm medium=email\&utm term=0 f7a5b1f394-08b8ba2ffa-59033269

27. Etzkowitz, H., Webster, A., Gebhardt, C., \& Terra, B. R. C. (2000). The future of the university and the university of the future: evolution of ivory tower to entrepreneurial paradigm. Research policy, 29(2), 313-330.

28. Fung, D., Besters-Dilger, J., \& van der Vaart, R. (2017). Excellent education in researchintensive universities.

29. Gallager, S. (2017). Executive Director of Northeastern University's Center for the Future of Higher Education and Talent Strategy. Retrieved from 
https://www.edsurge.com/news/2017-05-09-yes-there-s-disruption-in-college-market-

but-the-bigger-trend-is-growth-of-enabler-companies

30. Gereffi, G., \& Fernandez-Stark, K. (2016). Global value chain analysis: a primer.

31. Goddard, J. (2014) What do we mean by the 'civic university'? Presentation at Universities for Europe workshop, European Economic and Social Committee, 13 June2014 Retrieved from http://www.eesc.europa.eu/?i=portal.en.eventsand-activities-universities-foreuropepresentations.32448

32. Graham, R. (2014). Creating university-based entrepreneurial ecosystems: evidence from emerging world leaders. Massachusetts Institute of Technology.

33. HLG (2013). High Level Group on the Modernisation of Higher Education REPORT TO THE EUROPEAN COMMISSION ON Improving the quality of teaching and learning in Europe's higher education institutions. June 2013. Retrieved from http://ec.europa.eu/dgs/education culture/repository/education/library/reports/moderni sation en.pdf

34. Kennedy, J., Castro, D., \& Atkinson, R. D. (2016). Why it's time to disrupt higher education by separating learning from credentialing. Information Technology and Innovation Foundation (ITIF).

35. Kerr, C. (1987). A critical age in the university world: Accumulated heritage versus modern imperatives. European Journal of Education, 183-193.

36. Knight, J. (2015). International universities: Misunderstandings and emerging models?. Journal of Studies in International Education, 19(2), 107-121.

37. León, G., Leceta, J. M., \& Tejero, A. (2018). Impact of the EIT in the creation of an open educational ecosystem: UPM experience. International Journal of Innovation Science, 10(2), 178-206.

38. León, G. and Tejero, A. (2016). “Understanding Blended learning implementation in the EIT Digital Master School”. Report to the EIT Digital Going blended activity. July 2016.

39. Maassen, P., \& Stensaker, B. (2011). The knowledge triangle, European higher education policy logics and policy implications. Higher Education, 61(6), 757-769.

40. Marshall, S. J. (2018). Shaping the University of the Future. Springer.

41. Matt, C., Hess, T., \& Benlian, A. (2015). Digital transformation strategies. Business \& Information Systems Engineering, 57(5), 339-343.

42. Menezes, A., \& Pinto, P. (2016). Role of Industry in Developing the Education System.

43. Need, J. (2017). Let's Not Rush Into Disruptive Innovation. Inside Higher Ed. March 16, 2017. Retrieved from https://www.insidehighered.com/views/2017/03/16/downside-innovationand-disruption-essay

44. Normann, R., \& Ramirez, R. (1993). From value chain to value constellation: Designing interactive strategy. Harvard business review, 71(4), 65-77.

45. OECD (2012). Karine Tremblay, Diane Lalancette, Deborah Roseveare: Assessment of Higher Education Learning Outcomes. Feasibility Study Report. Volume 1: Design and implementation. OECD. Retrieved from http://www.oecd.org/edu/skills-beyondschool/AHELOFSReportVolume1.pdf

46. OECD (2017), Education at a Glance 2017: OECD Indicators, OECD Publishing, Paris. Retrieved from http://dx.doi.org/10.1787/eag-2017-en

47. Pisoni, G., Guri, G., Dion, G., Dalle, J.M., Renouard, F., Marchese, M., Tejero, A., Leon, G., Guseva, Y. \& Mutanen, O.P. (2018). Towards blended learning implementation of innovation and entrepreneurship (I\&E) education within EIT Digital: the models and lessons learnt. 
EDULEARN18. Paper presented at 10th annual International Conference on Education and New Learning Technologies conference. Palma de Mallorca (Spain). Retrieved from https://www.eitdigital.eu/fileadmin/files/2018/newsroom/Academy/EDULEARN18 2553 - FINAL.pdf

48. Rissola, G., HervÃ, F., Slavcheva, M., \& Jonkers, K. (2017). Place-Based Innovation Ecosystems: Espoo Innovation Garden and Aalto University (Finland) (No. JRC106122). Joint Research Centre (Seville site).

49. Skiba, D. J. (2012). Disruption in higher education: Massively open online courses (MOOCs). Nursing education perspectives, 33(6), 416-418.

50. SWD (2017). Commission Staff Working Document Accompanying the document "A renewed EU agenda for higher education". Communication from the Commission to the European Parliament, the Council, the European Economic and Social Committee and the Committee of the Regions. COM (2017) 247 final. SWD(2017) 164 final. Brussels, 30.5.2017. Retrieved from https://ec.europa.eu/education/sites/education/files/he-swd-2017165 en.pdf

51. SWD (2018) 14 final. Commission Staff Working Document Accompanying the document Proposal for a COUNCIL RECOMMENDATION on Key Competences for LifeLong Learning $\left\{\begin{array}{llll}\operatorname{COM}(2018) & 24 & \text { final } & \text { Retrieved }\end{array}\right.$ https://ec.europa.eu/education/sites/education/files/swd-recommendation-keycompetences-lifelong-learning.pdf

52. ULAB (2014). How to build the technical university of tomorrow. Coordinator: Gonzalo León. Final Report University Lab project (ULAB). FP7 Coordination and Support Action. January 2014.

53. Verger, A., Lubienski, C., \& Steiner-Khamsi, G. (Eds.). (2016). World yearbook of education 2016: The global education industry. Routledge. 